\title{
Role of E-Learning in the Quality Improvement of Higher Education
}

\author{
Dr. A. Kalaivani
}

\begin{abstract}
Education is a light that shows the mankind the right direction to surge. The purpose of education is not just making a student literate but adds rationale thinking, knowledgeable and self sufficiency. E-learning holds particular relevance to India as the youth constitute its major population and there is no other way to take education in such a scale without the intervention of technology. E-Learning includes all the forms of electronically supported learning and teaching including Edutech. In e-learning the instructional material and content may be delivered by any one of all electronic media including the internet, intranet, extranet, LAN, Satellite broad costs, audio video tapes. All lessons can be learned in just one click. Teachers who are giving online lectures are real with vast experiences, without going to school, without spending single rupee for enrollment that is the wisest thing to do if we are not financially equipped. E-Learning can be divided in several different types. They are Web-supplemented courses, Web-dependent courses In Mixed Mode courses etc. ELearning Approaches are, Computer-Based Learning, Computer Based Trainings, Computer-Supported Collaborative Learning, Technology Enhanced learning, etc. Communication technologies are generally categorized as asynchronous or synchronous. Asynchronous activities use technologies such as blogs, wikis, and discussion boards. Synchronous activities involve the exchange of ideas and information with one or more participants during the same period of time. Learning management system and learning content management system is software used for delivering tracking the managing training education Luskin says that the " $e$ " should be interpreted to mean exciting, energetic, enthusiastic, emotional, extended, excellent, and educational in addition to "electronic" that is a traditional national interpretation. This broader interpretation allows for $21^{\text {st }}$ century applications for the improvement of Higher Education. Rapid changes in the technologies are indicating that the role of E-learning in future will grow tremendously in education.
\end{abstract}

\section{Introduction}

Education is a light that shows the mankind the right direction to surge. The purpose of education is not just making a student literate but adds rationale thinking, knowledgeable and self sufficiency. When there is a willingness to change, there is hope for progress in any field. Use of technology to facilitate learning is accepted to be of value across educational institutions. E-learning holds particular relevance to India as the youth constitute its major population and there is no other way to take education in such a scale without the intervention of technology. E- Learning includes all the forms of electronically supported learning and teaching including Edutech. the information and communication systems, whether net work learning. This often involves both in the class room and out of class room, educational experiences in technology, even as advances continue in regard to device and curriculum. E - Learning applications and process include web - based learning; computer based learning, virtual education opportunities and digital collaboration. Content delivered via the Internet, Intranet, extranet, audiotape, satellite TV, and CD - ROM. It can be self paced or instructor led and includes media in the form of text, image, animation, streaming video and audio.

\section{Definition and importance of $\mathbf{E}$ - Learning}

The delivery of learning, training or education program by electronic means in assuming importance now a day. E - Learning is a type of teaching and learning that can be obtained by means of on line technology. E-learning can involve a greater of equipment than on line training or learning of as the same implies, "on line" involves using the internet or intranet. E - Learning involves all kinds of electronic media by utilizing all the potentialities of information technology. E - Learning has a truly vast perspective. The learner is connected to professional and experts both in and out side organization. He can select activities from a personal learning menu. In e - learning the instructional material and content may be delivered by any one of all electronic media including the internet, intranet, extranet, LAN, Satellite broad costs, audio video tapes. All lessons can be learned in just one click. Teachers who are giving online lectures are real with vast experiences, without going to school, without spending single rupee for enrollment that is the wisest thing to do if we are not financially equipped. 


\section{Types Of E - Learning}

E- Learning can be divided in several different types.

Web-supplemented courses focus on classroom-based teaching but include elements such as putting a course outline and lecture notes on line, use of e-mail and links to online resources.

Web-dependent courses require students to use the Internet for key elements of the programme such as online discussions, assessment, or online project/collaborative work, but without significant reduction in classroom time.

In Mixed Mode courses, the e-learning elements begin to replace classroom time. Online discussions, assessment, or project work replace some face-to-face teaching and learning.

\section{Approaches To E-Learning}

Computer-Based Learning: CBL is the use of computers as a key component of the educational environment. While this can include the use of computers in a classroom, the term more broadly refers to a structured environment in which computers are used for teaching purposes.

Computer Based Trainings are self-paced learning activities accessible via a computer or handheld device. CBTs typically present content in a linear fashion, much like reading an online books or manual. For this reason they are often used to teach static processes, such as using software or completing mathematical equations. The term computer-based training is often used interchangeably with web-based training (WBT) with the primary difference being the deliver method. Where CBTs are typically delivered via CD-ROM, WBTs are delivered via the internet using a web browser. CBTs can be a good alternative to printed learning materials since rich media, including videos or animations, can easily be embedded to enhance the learning. Another advantage to CBTs is that they can be easily distributed to a wide audience at a relatively low cost once the initial development is completed.

Computer-Supported Collaborative Learning (CSCL) is one of the most promising innovations to improve teaching and learning with the help of modern information and communication technology. Most recent developments in CSCL have been called E-Learning, but the concept of collaborative or group learning whereby instructional methods are designed to encourage or require students to work together on learning tasks has existed much longer. It is widely agreed to distinguish learning from the traditional "direct transfer" model in which the instructor is assumed to be the distributor of knowledge and skills, which is often given the neologism E-Learning.

Technology Enhanced learning (TEL) has the goal to provide socio-technical innovations, and also improving efficiency and cost Effectiveness for e-learning practices, regarding individuals and organizations, independent of time, place and pace. The field of TEL therefore applies to the support of any learning activity through technology.

\section{Communication Technologies Used In E-Learning}

Communication technologies are generally categorized as asynchronous or synchronous. Asynchronous activities use technologies such as blogs, wikis, and discussion boards. The idea here is that participants may engage in the exchange of ideas or information without the dependency of other participants' involvement at the same time. This learning gives students the ability to work at their own place. This is particularly beneficial for students which have health problems or have child care responsibilities and regularly learning the home to attend lectures is difficult. They have the opportunity to complete their work in a low stress environment and within a more flexible time frame.

Synchronous activities involve the exchange of ideas and information with one or more participants during the same period of time. Synchronous activities occur with all participants' joins in at one, as with an online chat session or a virtual classroom or meeting. Learning management system and learning content management system is software used for delivering tracking the managing training education. LMSs range from systems for managing training educational records to software for author content courses, reusable content object.

Computer-aided assessment ranging from automated multiple-choice tests to more sophisticated systems is becoming increasingly common. With some systems, feedback, can be geared towards a student's specific mistakes on the computer can navigate the student through a series of questions adapting as what the student appears to have learned or not learned.

\section{E-Learning Improve The Quality Of Higher Education}

E-Learning can also be seen as a promising way for improving the quality of higher education and effectiveness of learning. It can give increased flexibility of learning experience to student, enhances access to information resources for more students; the potential to drive innovative and effective ways of learning and teaching at very low marginal cost among the teachers and learners. E - Learning could also lead to the 
enhancement of quality in higher education by leading to innovative pedagogical methods, new ways of learning and interacting by the easy sharing of the new practices among learners and teachers communities, as well as by more transparency and easier comparison and cross fertilization of materials and methods.

\section{Conclusion}

The e-learning system not only provides learning objectives, but also evaluates the progress of the student and credit can be earned towards higher learning institutions. The Internet allows for learning to be directed at one's current objectives.. E-learning is naturally suited to distance learning and flexible learning, but can also be used in conjunction with face-to-face teaching. Luskin says that the "e" should be interpreted to mean exciting, energetic, enthusiastic, emotional, extended, excellent, and educational in addition to "electronic" that is a traditional national interpretation. This broader interpretation allows for $21^{\text {st }}$ century applications and brings learning and media psychology into the equation. Hence, the students not longer want to just learn about but want to learn to be, by constructing content instead of absorbing. Students require interactivity and using modern technologies like e-learning, M-learning, virtual learning and web learning as a teaching device allows this interactivity to occur. With the emergence Social networking, blogging, and You Tube, students expect to be able to utilize modern technology on the fly to connect everything.

\section{References}

[1]. Allen, I,.E., and Seaman, J., (2008), staying the course; on line education in the United states 2009, Needham MA; Sloan consortium.

[2]. Adams J., (2004), Second Generation e-learning. An Action -Based Exploration of Design and York University.

[3]. Bates A. and Poole, G. (2003), Effective Teaching with Technology in Higher Education.

[4]. Judith A. Pirani (2010), Supporting E-Learning in Higher Education, Roadmap-Educause Centre for Applied Research.

[5]. Nahy, A (2005), The Impact of E - Learning in: Bruck. P.A. et. al. E- content, Technologies and perspectives for the European Market, Berline:springer - verlab, po.79-98.

\section{Web-Resources}

http//www.ISTE.org.

http://www.pt.3.org.

http://www.jrc.ec.europa.eu.

http://www.newhorizones.org. 